\title{
Effect of Fertilizer Granulates on lonic and Weight Relations Among Macronutrients in Spring Rape Seeds
}

\author{
Ewa Możdżer ${ }^{1 *}$, Stanisław Jałoszyński ${ }^{1}$ \\ ${ }^{1}$ West Pomeranian University of Technology in Szczecin, Department of Soil Science, Grassland Mangement \\ and Environmental Chemistry, Słowackiego17, 71-434 Szczecin, Poland \\ * Corresponding author's e-mail: ewa.mozdzer@zut.edu.pl
}

\begin{abstract}
The experiment consisted in testing four fertilizer granulates produced from waste in the vegetation experiment. The waste used to produce granulates included: ash from lignite due to its deacidifying properties, industrial sewage sludge and sawdust due to considerable abundance of nutrients for plants. The recipe for the chemical composition of granulates was devised on the basis of chemical properties of the waste. The fertilizer granulates were characterized by fairly high content of calcium and organic carbon, and less of sulfur, phosphorus, potassium and magnesium. The contents of heavy metals did not exceed the permissible standards. The test plant was rapeseed of Larissa cultivar. The content of macronutrients was determined in rape seeds. The following ionic relations $\mathrm{K}: \mathrm{Mg}$, $\mathrm{K}: \mathrm{Ca}, \mathrm{K}:(\mathrm{Ca}+\mathrm{Mg}), \mathrm{Ca}: \mathrm{Mg}$ and weight proportions $\mathrm{Ca}: \mathrm{P}$ and $\mathrm{N}: \mathrm{S}$, were calculated. The research indicated that the applied single doses of fertilizer granulates $\mathrm{A}, \mathrm{B}, \mathrm{C}$ and $\mathrm{D}$ significantly expanded the $\mathrm{Ca}: \mathrm{Mg}$ ion relations, but did not affect the increase in $\mathrm{K}: \mathrm{Ca}, \mathrm{K}:(\mathrm{Ca}+\mathrm{Mg}), \mathrm{N}: \mathrm{S}$ and $\mathrm{Ca}: \mathrm{P}$ in rape seeds compared to the control. Double doses of granulates compared to the single ones resulted in a significant narrowing of the ionic ratio $\mathrm{K}: \mathrm{Ca}$ and significant extension of $\mathrm{Ca}: \mathrm{Mg}$ and $\mathrm{N}: \mathrm{S}$ in the seeds of the test plant. Triple doses of fertilizer granulates significantly reduced the ionic relations $\mathrm{K}: \mathrm{Ca}, \mathrm{K}:(\mathrm{Ca}+\mathrm{Mg})$ and $\mathrm{N}: \mathrm{S}$, but did not cause changes in the $\mathrm{Ca}: \mathrm{Mg}$ and $\mathrm{Ca}: \mathrm{P}$ ratio in rape seeds. The aim of the study was to determine the impact of 4 granulates produced from waste on the formation of the most important ionic ratios and weight proportion of elements in the yields of spring rape seeds.
\end{abstract}

Keywords: granulates, rape seeds, ionic relations, weight proportions

\section{INTRODUCTION}

It is estimated that Polish soils are characterized by an acidic or very acidic reaction in over $60 \%$ of agricultural land, Skłodowski and Bielska [2009]. Acidic soils limit the transition of some macronutrients from forms that are available to plants to the unavailable ones (e.g. phosphorus), the transfer of micronutrients from unavailable into available forms to plants. There may also be inhibition of the development of microorganisms living in the soil involved in the decomposition of organic matter and poor root development. Then plants have less opportunity to take water and nutrients up from deeper soil layers.

Therefore, the research was conducted on the possibility of reducing the degree of acidification of soils and increasing the organic matter and nutrients for plants. For this purpose, the fertilizer granulates were prepared from waste, among others, ash from lignite that can be used for deacidification of soils, sewage sludge and sawdust abundant in organic matter and nutrients for plants [Antonkiewicz 2010, Antonkiewicz et al. 2018, Krzywy-Gawrońska 2012, Hargreaves et al. 2008, He et al. 2009].

Reliable factors confirming the qualitative characteristics of harvested crops are the ionic ratios between the selected elements: $\mathrm{K}: \mathrm{Mg}$, $\mathrm{K}:(\mathrm{Ca}+\mathrm{Mg}), \mathrm{K}: \mathrm{Ca}, \mathrm{Ca}: \mathrm{Mg}, \mathrm{Ca}: \mathrm{P}$ oraz N:S Majcherczak et al. [2006]. According to Wyszkowski [2001] as well as Wyszkowski and Ciećko [2002], the ionic proportions $\mathrm{K}:(\mathrm{Ca}+\mathrm{Mg})$ and $\mathrm{Ca}: \mathrm{Mg}$ should be close to 1.62 and 3.0, respectively. 
Łabuda et al. [1992] indicate that the optimal ionic proportions $\mathrm{K}: \mathrm{Ca}$ and $\mathrm{K}: \mathrm{Mg}$ in cereal plants should be at the level of 4 . At the same time, it was found that the ratio most often taken into account in the case of sulfur deficiency in the plant is $\mathrm{N}: \mathrm{S}$ ionic ratio [Grzebisz and Przygocka-Cyna 2007].

\section{MATERIAL AND METHODS}

The two-factor experiment was carried out in a randomized block design with a control object in four replications. The factor I consisted of the types of granulates, and factor II - three doses. Four fertilizer granulates made from waste (ash from lignite, sewage sludge, sawdust) were used for the vegetation-pot experiment. On the basis of the chemical properties of the waste, their material compositions were developed (Table1).

Soil with the granulometric composition of strong loamy sand included in the good rye complex and bonitation class IVb, used for investigations originated from Lipnik. It was characterized by a slightly acid reaction, narrow $\mathrm{C}: \mathrm{N}$ ratio and low organic carbon content. The content of available forms of phosphorus (60.9 $\mathrm{mg} \cdot \mathrm{kg}^{-1} \mathrm{~d} . \mathrm{m}$.) potassium (121 mg. $\mathrm{kg}^{-1} \mathrm{~d} . \mathrm{m}$.) and magnesium (42,5 mg $\mathrm{kg}^{-1} \mathrm{~d} . \mathrm{m}$.) and for plants was medium (Table 2). Due to the fact that the granulates were produced with the use of ashes and sewage sludge, the total content of heavy metals was also determined in the soil. Total content of $\mathrm{Cd}$, $\mathrm{Cu}, \mathrm{Cr}, \mathrm{Ni}, \mathrm{Pb}$ and $\mathrm{Zn}$ was $0.22 ; 8.60 ; 8.80 ; 7.12$; 12.8 and $35.7 \mathrm{mg} \cdot \mathrm{kg}^{-1} \mathrm{~d} . \mathrm{m}$., respectively, and did not exceed the permissible standards for crops and land reclamation contained in the Minister of the Natural Environment [Journal of Laws, 2016, item 1395]. The test plant was rapeseed of Larissa cultivar.

The delivered soil was sifted to eliminate larger impurities and stones, and then in an amount of $9 \mathrm{~kg}$ placed into pots. The granulate doses were calculated based on their nitrogen content. Dose I, II and III were: $0.24 \mathrm{~g}, 0.48 \mathrm{~g}$ and $0.72 \mathrm{~g} \mathrm{~N} \cdot$ pot which corresponds to 80,160 and $240 \mathrm{~kg} \mathrm{~N} \cdot \mathrm{ha}^{-}$ ${ }^{1}$, respectively.The fertilizer granulates were applied to the pots filled with the soil in accordance with the experimental scheme. Then 20 rape seeds were sown. The pots were placed under a roof, eliminating the impact of atmospheric precipitation. After reaching the height of $10 \mathrm{~cm}$ by rapeseed, selection was made, leaving 5 plants in each pot. The experiment required the post-crop foliar feeding with nitrogen in the form of urea 5 weeks after rapeseed plant emergence. The size of nitrogen dose per pot was $0.276 \mathrm{~g} \mathrm{~N}$.

The harvest of test plants was carried out at the production maturity stage. The rapeseed was collected on July 26. After the harvest of plants, the size of the yield was determined and the samples were taken for laboratory tests. The averaged seed samples were subjected to chemical analyses in duplicate. On the basis of the determined $\mathrm{N}, \mathrm{P}, \mathrm{K}, \mathrm{Ca}, \mathrm{Mg}$ and $\mathrm{S}$ contents in the seeds of the test plant, ionic relations $\mathrm{K}: \mathrm{Mg}, \mathrm{K}: \mathrm{Ca}$, $\mathrm{K}:(\mathrm{Mg}+\mathrm{Ca}), \mathrm{Ca}: \mathrm{Mg}$ and proportions of $\mathrm{Ca}: \mathrm{P}$ and $\mathrm{N}: \mathrm{S}$ were calculated.

The material composition of granulates and the content of some macronutrients in rape seeds were published in the work of Krzywy et al. [2013].

\section{ANALYTICAL METHODS}

In rape seeds, the nitrogen content was determined using the Kjeldahl method PN ISO 13878, phosphorus by means of the Barton colorimetric method on the Perkin Elmer Lambda EZ 150 device, potassium, calcium and magnesium by the atomic absorption spectrometry (AAS) and sulfur applying the nephelometric method. The stock solution was obtained after wet digestion of plant material in a mixture of perchloric(VII) acid and nitric $(\mathrm{V})$ acid at the ratio $3: 1$ according to $\mathrm{PN}$ ISO 11466 standard.

Ionic relations and weight proportions of macronutrients in rape seeds were analyzed

Table 1. Material composition of fertilizer blends expressed in \% d.m.

\begin{tabular}{|c|c|c|c|c|c|}
\hline \multirow{2}{*}{$\begin{array}{c}\text { Type of } \\
\text { granulate }\end{array}$} & $\begin{array}{c}\text { industrial sewage } \\
\text { sludge }\end{array}$ & brown coal ash & sawdust & ammonia phosphate & potassium salt \\
\hline & \multicolumn{5}{|c|}{$w \%$} \\
\hline$A$ & 30 & 30 & 10 & 15 & 15 \\
\hline B & 40 & 20 & 10 & 15 & 15 \\
\hline $\mathrm{C}$ & 20 & 40 & 10 & 15 & 15 \\
\hline $\mathrm{D}$ & 50 & 20 & 10 & 10 & 10 \\
\hline
\end{tabular}


Table 2. Some fertility indicators of the soil used for the vegetation-pot experiment

\begin{tabular}{|c|c|c|c|c|c|c|c|c|c|c|c|}
\hline \multirow{3}{*}{$\mathrm{pH}_{\mathrm{KCl}}$} & & \multicolumn{6}{|c|}{ total content } & \multirow{3}{*}{$\mathrm{C}: \mathrm{N}$} & \multirow{2}{*}{\multicolumn{3}{|c|}{\begin{tabular}{|c} 
content of assimilable forms \\
in $\mathrm{mg} \cdot \mathrm{kg}^{-1} \mathrm{~d} \cdot \mathrm{m}$ \\
\end{tabular}}} \\
\hline & \multicolumn{7}{|c|}{ in $\mathrm{g} \cdot \mathrm{kg}^{-1} \mathrm{~d} . \mathrm{m}$} & & & & \\
\hline & $\mathrm{C}_{\text {org. }}$ & $\mathrm{N}$ & $\mathrm{P}$ & $\mathrm{K}$ & $\mathrm{Ca}$ & $\mathrm{Mg}$ & $S$ & & $\mathrm{P}$ & $\mathrm{K}$ & $\mathrm{Mg}$ \\
\hline 6.0 & 9.63 & 0.86 & 1.50 & 2.57 & 2.11 & 0.56 & 1.25 & 11.2 & 60.9 & 121 & 42.5 \\
\hline
\end{tabular}

statistically on the basis of a two-factor analysis of variance in a random block design (factor I type of granulate, factor II - increasing doses). In order to determine the significance of differences, half-confidence intervals using the Tukey test were used for the level of $p=0.05$, with a help of FR-ANALWAR software according to Rudnicki.

\section{RESULTS AND DISCUSSION}

Adjustment of ionic relations between $\mathrm{K}: \mathrm{Mg}$, $\mathrm{K}: \mathrm{Ca}, \mathrm{K}:(\mathrm{Ca}+\mathrm{Mg}), \mathrm{Ca}: \mathrm{Mg}, \mathrm{N}: \mathrm{S}, \mathrm{Ca}: \mathrm{P}-$ which are involved in physiological and biochemical processes in plants, towards optimal direction, ensures obtaining the high-quality yields. Table 3 summarizes the optimal ion ratios based on the available literature. The fertilizer granulates applied to the soil can significantly influence the formation of ionic relations in crop plants, especially those for animal feed.

The influence of fertilizer granulates A, B, $\mathrm{C}$ and $\mathrm{D}$ on ionic and weight relations of macronutrients in spring rape seeds is presented in Tables 4 and 5. The results of the study indicated that under the influence of applied granulates, ion relations $\mathrm{K}: \mathrm{Ca}$ and $\mathrm{K}:(\mathrm{Ca}+\mathrm{Mg})$ in rape seeds were wider, while $\mathrm{K}: \mathrm{Mg}$, Ca:Mg, N:S and Ca:P were narrower compared to the optimal values (Tables 4 and 5).

On the control objects, it was found that the ionic relations $\mathrm{K}: \mathrm{Mg}$ (4.76), Ca: $\mathrm{Mg}(0.85)$, Ca:P $(0.40)$ and $\mathrm{N}: \mathrm{S}$ (3.33), in rape seeds were narrowed, and $\mathrm{K}: \mathrm{Ca}(5.59)$ and $\mathrm{K}:(\mathrm{Ca}+\mathrm{Mg}) 2.57 \mathrm{ex}-$ tended in relation to the optimal values.

Fertilizers A, B, C and D contributed to the expansion of $\mathrm{K}: \mathrm{Mg}$ ionic relation in rapeseeds compared to the control by $4.62 \%, 12.4 \%, 2.73 \%$ and $8.82 \%$, respectively, (Tables 2 and 4). Increasing doses of granulate B (40\% sludge, $20 \%$ ash, $10 \%$ sawdust, $15 \%$ ammonium phosphate, $15 \% \mathrm{KCl}$ ) and D (50\% sewage sludge, $20 \%$ ash, $10 \%$ sawdust, $10 \%$ ammonium phosphate, $10 \% \mathrm{KCl}$ ) contributed to the expansion of the ionic ratio $\mathrm{K}: \mathrm{Mg}$ in seeds towards the optimal value. The applied III dose of granulate B contributed to obtaining the most optimal ionic ratio $\mathrm{K}: \mathrm{Mg}$ in the test plant, and granulate $\mathrm{C}$ - narrowing by $12.7 \%$ (Table 4). The first dose of granulate $\mathrm{C}(20 \%$ sewage sludge, $40 \%$ ash, $10 \%$ sawdust, $15 \%$ ammonium phosphate, $10 \% \mathrm{KCl}$ ) applied resulted in the extension of the relation $\mathrm{K}: \mathrm{Mg}$ in rape seeds to the greatest extent (by $4.16 \%$ ) in comparison to the applied III dose. The introduction of a tripled dose of granulate B resulted in the $\mathrm{K}: \mathrm{Mg}$ ratio being extended towards the optimal value compared to the single dose by $2.26 \%$. While analyzing the effect of applied fertilizer granulates A, C and B, it was found that the administered dose II and III caused a narrowing of the ionic relation $\mathrm{K}: \mathrm{Mg}$ in rape seeds compared to the first dose (Table 4). Increasing doses of fertilizer granulates did not have any significant impact on the formation of the ionic relation $\mathrm{K}: \mathrm{Mg}$ in the seeds of the test plant.

The ionic relations $\mathrm{K}: \mathrm{Ca}$ under the influence of applied fertilizer granulates A, B, C and D were wider than the optimal value. Similar results were obtained by Krzywy et al. [2002]. These results indicate that in order to obtain the optimal ionic relations $\mathrm{K}: \mathrm{Ca}$, calcium should be introduced into the soil. The introduction of fertilizers containing calcium would be expedient, because under the influence of the urea used in the experiment, the soil $\mathrm{pH}_{\mathrm{KCl}}$ decreased. The narrowest ionic relation $\mathrm{K}: \mathrm{Ca}$ in the test plant was obtained under the influence of the applied III dose of granulate A (4.29), while the widest - under the influence

Table 3. Optimal ion-related and weight relations of macronutrients in cultivated plants according to Majcherczak et al. (2006)

\begin{tabular}{|c|c|c|c|c|c|}
\hline $\mathrm{K}: \mathrm{Mg}$ & $\mathrm{K}: \mathrm{Ca}$ & $\mathrm{K}:(\mathrm{Ca}+\mathrm{Mg})$ & $\mathrm{Ca}: \mathrm{Mg}$ & $\mathrm{N}: \mathrm{S}$ & $\mathrm{Ca}: \mathrm{P}$ \\
\hline $6: 1$ & $2: 1$ & $1.6-2.2: 1$ & $3: 1$ & $15-16: 1$ & $2: 1$ \\
\hline
\end{tabular}


Table 4. Ionic relations $\mathrm{K}: \mathrm{Mg}, \mathrm{K}: \mathrm{Ca}, \mathrm{K}:(\mathrm{Ca}+\mathrm{Mg})$ and $\mathrm{Ca}: \mathrm{Mg}$ in rape seeds expressed in mmol per mass unit obtained under the influence of fertilizer granulates

\begin{tabular}{|c|c|c|c|c|c|c|c|c|}
\hline \multirow{3}{*}{ Fertilizer object } & \multicolumn{4}{|c|}{$\mathrm{K}: \mathrm{Mg}$} & \multicolumn{4}{|c|}{$\mathrm{K}: \mathrm{Ca}$} \\
\hline & \multicolumn{8}{|c|}{ dose granulates } \\
\hline & I & II & III & Mean & 1 & II & III & Mean \\
\hline A & 4,99 & 4.98 & 4.96 & 4.98 & 5.12 & 4.66 & 4.29 & 4.69 \\
\hline B & 5,29 & 5.35 & 5.41 & 5.35 & 5.70 & 5.44 & 5.12 & 5.42 \\
\hline C & 5,00 & 4.87 & 4.80 & 4.89 & 5.07 & 4.81 & 4.63 & 4.84 \\
\hline D & 5.18 & 5.31 & 5.04 & 5.18 & 5.68 & 5.47 & 5.39 & 5.51 \\
\hline Mean & 5.11 & 5.13 & 5.05 & 5.10 & 5.40 & 5.10 & 4.86 & 5.12 \\
\hline Control & \multicolumn{4}{|c|}{4.76} & \multicolumn{4}{|c|}{5.59} \\
\hline \multicolumn{5}{|c|}{$\begin{array}{l}\mathrm{LSD}_{0.05} \text { for: type of granulate }-0.121 \\
\text { dose }-0.094 \\
\text { interaction }- \text { n.s. }\end{array}$} & \multicolumn{4}{|c|}{$\begin{array}{c}0.274 \\
0.213 \\
\text { n.s. }\end{array}$} \\
\hline \multicolumn{5}{|c|}{$\mathrm{K}:(\mathrm{Ca}+\mathrm{Mg})$} & \multicolumn{4}{|c|}{ Ca:Mg } \\
\hline A & 2.52 & 2.40 & 2.30 & 2.41 & 0.97 & 1.06 & 1.15 & 1.06 \\
\hline B & 2.74 & 2.70 & 2.63 & 2.69 & 0.92 & 0.99 & 1.06 & 0.99 \\
\hline$C$ & 2.51 & 2.42 & 2.33 & 2.42 & 0.98 & 1.01 & 1.04 & 1.01 \\
\hline D & 2.71 & 2.69 & 2.60 & 2.67 & 0.91 & 0.97 & 0.94 & 0.94 \\
\hline Mean & 2.62 & 2.55 & 2.47 & 2.55 & 0.95 & 1.01 & 1.05 & 1.00 \\
\hline Control & \multicolumn{4}{|c|}{2.57} & \multicolumn{4}{|c|}{0.85} \\
\hline \multicolumn{5}{|c|}{$\begin{aligned} \mathrm{LSD}_{0.05} \text { for: type of granulate }-0.118 \\
\\
\text { dose }-0.09 \\
\text { interaction }- \text { n.s. }\end{aligned}$} & \multicolumn{4}{|c|}{$\begin{array}{l}0.051 \\
0.040 \\
0.088\end{array}$} \\
\hline
\end{tabular}

Table 5. Weight proportions N:S and Ca:P in rape seeds expressed in mmol per mass unit obtained under the influence of fertilizer granulates

\begin{tabular}{|c|c|c|c|c|c|c|c|c|}
\hline \multirow{3}{*}{ Fertilizer object } & \multicolumn{4}{|c|}{$\mathrm{N}: \mathrm{S}$} & \multicolumn{4}{|c|}{ Ca:P } \\
\hline & \multicolumn{8}{|c|}{ dose granulates } \\
\hline & 1 & II & III & Mean & I & II & III & Mean \\
\hline$A$ & 3.40 & 3.50 & 3.48 & 3.46 & 0.43 & 0.46 & 0.50 & 0.46 \\
\hline B & 3.54 & 3.80 & 3.70 & 3.68 & 0.41 & 0.42 & 0.42 & 0.42 \\
\hline $\mathrm{C}$ & 3.30 & 3.35 & 3.34 & 3.33 & 0.43 & 0.45 & 0.48 & 0.45 \\
\hline D & 3.34 & 3.39 & 3.53 & 3.42 & 0.41 & 0.42 & 0.42 & 0.42 \\
\hline Mean & 3.40 & 3.51 & 3.51 & 3.47 & 0.42 & 0.44 & 0.46 & 0.44 \\
\hline Control & \multicolumn{4}{|c|}{3.33} & \multicolumn{4}{|c|}{0.40} \\
\hline \multicolumn{5}{|c|}{$\begin{array}{l}\text { LSD }_{0.05} \text { for: type of granulate }-0.141 \\
\text { dose }-0.109 \\
\text { interaction }- \text { n.s. }\end{array}$} & \multicolumn{4}{|c|}{$\begin{array}{c}0.031 \\
0.024 \\
\text { n.s. }\end{array}$} \\
\hline
\end{tabular}

of single dose of granulate B applied. The tested fertilizer granulates A, B, C and D resulted in the expansion of $\mathrm{K}: \mathrm{Ca}$ ionic relation in rape seeds compared to the control by $19.8 \%, 3.13 \%, 15.5 \%$ and $1.45 \%$, respectively (Table 3 ). Introduction of the second and third dose of granulates A, B, C and $\mathrm{D}$ contributed to the successive narrowing of the ionic ratio $\mathrm{K}: \mathrm{Ca}$ compared to the single dose used. A single dose of fertilizer granulates A, B, $\mathrm{C}$ and $\mathrm{D}$ resulted in the extension of $\mathrm{K}$ :Ca ratio in rape seeds by $19.3 \%, 11.3 \%, 9.50 \%$ and $5.38 \%$, respectively, compared to the III dose applied.

A slightly optimized ionic relation $\mathrm{K}:(\mathrm{Ca}+\mathrm{Mg})$ was obtained in the rape seeds in all fertilizer objects. The ionic relation $\mathrm{K}:(\mathrm{Ca}+\mathrm{Mg})$ in the control of the test plant was 2.57, and for the objects with applied granulates A, B, C and D, irrespective of the dose size, it ranged from 2.41 to 2.69 (Table 4). The applied fertilizer granulates $\mathrm{A}$ and $\mathrm{C}$ in the second and third dose resulted in the narrowing of the ionic relation $\mathrm{K}:(\mathrm{Ca}+\mathrm{Mg})$ in the rape seeds towards the optimal value. Single doses of granulates $\mathrm{B}$ and $\mathrm{D}$ extended the ionic ratio $\mathrm{K}:(\mathrm{Ca}+\mathrm{Mg})$ in rape seeds compared to the control by 6.61 and $5.44 \%$, respectively. Introduction of the second and third dose of granulates $\mathrm{A}, \mathrm{B}, \mathrm{C}$ and $\mathrm{D}$ contributed to narrowing the ionic ratio $\mathrm{K}:(\mathrm{Ca}+\mathrm{Mg})$ towards the optimal value in 
comparison to the single dose used. A single dose of fertilizer granulates A, B, C and D resulted in an increase in the proportion of $\mathrm{K}:(\mathrm{Ca}+\mathrm{Mg})$ by $9.56 \%, 4.18 \%, 7.72 \%$ and $4.23 \%$, respectively, as compared to the third dose used. The results of the research show that it is possible to reduce the doses of granulates A, B, C and D in appropriate proportions without worrying about the value of optimal proportion $\mathrm{K}:(\mathrm{Ca}+\mathrm{Mg})$.

Fertilizers A, B, C and D caused the $\mathrm{Ca}: \mathrm{Mg}$ ionic relations to expand in rape seeds compared to the control by $24.7 \%, 16.5 \%, 18.8 \%$ and $10.6 \%$, respectively. The applied third dose of granulate A contributed to obtaining the most favorable ionic ratio of $\mathrm{Ca}: \mathrm{Mg}$ in the test plant, and granulate D used in a single dose for narrowing, in comparison to other fertilizer objects (Table 4). Introduction of a tripled dose of granulates $A$ and $\mathrm{B}$ resulted in the $\mathrm{Ca}: \mathrm{Mg}$ ratio being extended towards the optimal value compared to the single dose by $18.5 \%$ and $15.2 \%$, respectively. While analyzing the effect of applied fertilizer granulates A, B and C, it was found that the applied III dose contributed significantly to the extension of $\mathrm{Ca}: \mathrm{Mg}$ ionic relations in rape seeds compared to the first dose and the control object. The differences in the effect exerted by the fertilizer granulates $\mathrm{B}$ and $\mathrm{D}$ on the values of ionic relations and the weight proportion of ingredients in rape seeds were negligible. Similarly, the fertilizer granulates $\mathrm{A}$ and $\mathrm{C}$ did not significantly differentiate the $\mathrm{K}: \mathrm{Mg}, \mathrm{K}: \mathrm{Ca}, \mathrm{K}:(\mathrm{Ca}+\mathrm{Mg}), \mathrm{Ca}: \mathrm{Mg}$ and $\mathrm{Ca}: \mathrm{P}$ ratios in the seeds of the test plant.

The $\mathrm{N}: \mathrm{S}$ weight proportions ranged from 3.30 to 3.80 under the influence of the applied fertilizer granulates (Table 5). Doubling and tripling the dose of granulates A, B and D increased the weight proportion of $\mathrm{N}: \mathrm{S}$ relative to the single dose and control. The weight proportion N:S under the influence of single dose of fertilizer granulates ranged from 3.30 to 3.54. Doubling the doses of fertilizer granulates A, B, C and D used extended the ionic relation $\mathrm{N}: \mathrm{S}$ by $5.1 \%, 14.1 \%, 0.60 \%$ and $1.80 \%$, respectively compared to the control. The applied fertilizer granulates A, B, C and D at the applied doses significantly narrowed the weight proportion $\mathrm{N}: \mathrm{S}$ in relation to the optimal value. The rape seeds from objects, in which fertilizer granulate B was used were characterized by significantly broader $\mathrm{N}: \mathrm{S}$ ratio compared to other fertilizer objects. The differences in the effect of granulates A, D and C on the weight proportion of $\mathrm{N}: \mathrm{S}$ in the test plant seeds were negligible.

The N:S weight ratios were the most narrowed in the fertilizer objects with $\mathrm{C}$ granulate. A significant weight proportion of $\mathrm{N}: \mathrm{S}$ is most likely due to the nitrogen content in the seeds, which is a consequence of larger intake of this element compared to the needs of oilseeds or cereals. These data indicate that it is possible to increase the dose of mineral fertilizers containing nitrogen and sulfur in appropriate proportions. Jamal et al. [2010] confirm the results obtained by other authors, according to which the increase in sulfur content in plants is related to the availability of this element originating from the soil solution.

Many authors, based on their own research, state that the interaction of sulfur and nitrogen as essential fertilizers necessary for the synthesis of amino acids included in proteins is very important [Barczak et al. 2016, Barczak et al. 2017, Podleśna and Kocoń 2009, Schung and Haneklaus 2000]. The quantitative $\mathrm{N}: \mathrm{S}$ ratio is a measure of the interaction of these components. The widest $\mathrm{N}: \mathrm{S}$ ionic ratio in rapeseeds was recorded in object with applied second dose of granulate B (3.80) and it was over twice lower in relation to the proportion of weight in rape seeds (9.3:1) recorded by Šiaudnis [2010] and Grygierzec et al. [2015] in the biomass of grasslands (9.2-12.6:1). The weight proportions of $\mathrm{N}: \mathrm{S}$ were narrowed in comparison to the optimal values on other fertilizer objects.

Ionic relations and weight proportions of macronutrients in plants are diverse due to the species diversity. There were significant differences between the content of macronutrients, their proportions and requirements for products intended for fodder. Janowska-Miąsik [2015] noted the average ratio of $\mathrm{K}:(\mathrm{Mg}+\mathrm{Ca})$ at 1.51 . The ionic ratios obtained by Jarnuszewski and Meller-[2013] fluctuated at the levels of: $\mathrm{K}: \mathrm{Mg}-3.13 ; \mathrm{K}: \mathrm{Ca}-5.65$ and $\mathrm{K}:(\mathrm{Mg}+\mathrm{Ca})-1.15$. On the other hand, the ionic relations obtained in own studies are broader for $\mathrm{K}: \mathrm{Mg}$ and $\mathrm{K}:(\mathrm{Mg}+\mathrm{Ca})$, and narrower for $\mathrm{K}: \mathrm{Ca}$ in comparison to those given by the abovementioned authors. The obtained proportions in the test plant slightly differed from values that are considered optimal in arable crops for fodder.

Fertilizers A, B, C and D caused a slight extension of $\mathrm{Ca}: \mathrm{P}$ weight proportion in rapeseed compared to the control by $5.0 \%, 10.0 \%, 15.0 \%$ and $10.0 \%$, respectively (Table 5 ). The applied 
third dose of granulate A contributed to obtaining the widest proportion of $\mathrm{Ca}: \mathrm{P}$ in the test plant, and granulates $\mathrm{B}$ and $\mathrm{D}$ used in a single dose - to narrowing in comparison to other fertilizer objects (Table 5). Introduction of a tripled dose of granulates $\mathrm{A}$ and $\mathrm{C}$ resulted in the $\mathrm{Ca}: \mathrm{P}$ proportion being extended towards the optimal value in comparison to the single dose by $16.2 \%$ and $17.0 \%$, respectively. While analyzing the effect of applied fertilizer granulates-A, B, C and D, it was found that the first dose applied contributed significantly to the increase in the weight proportion of $\mathrm{Ca}: \mathrm{P}$ in rape seeds compared to the control. On the other hand, the second and third dose caused a narrowing of this proportion.

In summary, single doses of fertilizer granulates A, B, C and D significantly expanded the $\mathrm{Ca}: \mathrm{Mg}$ ion relations, but did not affect the increase in $\mathrm{K}: \mathrm{Ca}, \mathrm{K}:(\mathrm{Ca}+\mathrm{Mg}), \mathrm{N}: \mathrm{S}$ and $\mathrm{Ca}: \mathrm{P}$ in seeds rape compared to control. Double doses of fertilizer granulates resulted in a significant narrowing of the ionic ratio $\mathrm{K}: \mathrm{Ca}$ and significant extension of $\mathrm{Ca}: \mathrm{Mg}$ and $\mathrm{N}: \mathrm{S}$ in the seeds of the test plant, compared to single ones. The triple doses of fertilizer granulates significantly reduced the ionic relations $\mathrm{K}: \mathrm{Ca}, \mathrm{K}:(\mathrm{Ca}+\mathrm{Mg})$ and $\mathrm{N}: \mathrm{S}$, as compared to double one, but did not cause changes in the $\mathrm{Ca}: \mathrm{Mg}$ and $\mathrm{Ca}: \mathrm{P}$ ratio in rape seeds.

\section{CONCLUSIONS}

1. Chemical composition of fertilizer granulates largely depended on the quantity and chemical properties of the waste used to produce them.

2. Under the influence of granulates A, B, C and $\mathrm{D}$, the ionic relations of elements $\mathrm{K}: \mathrm{Mg}, \mathrm{K}: \mathrm{Ca}$ and $\mathrm{K}:(\mathrm{Ca}+\mathrm{Mg})$ were significantly expanded and $\mathrm{Ca}: \mathrm{Mg}, \mathrm{Ca}: \mathrm{P}$ and $\mathrm{N}: \mathrm{S}$ significantly decreased in rape seeds as compared to the control object.

3. Applied granulates B and D resulted in the rape seeds extension of the ionic ratio $\mathrm{K}: \mathrm{Mg}$ towards the optimal value.

4. The research indicated that the applied granulates A, B, C and D contributed to slightly extended ionic ratios $\mathrm{K}: \mathrm{Mg}, \mathrm{K}:(\mathrm{Ca}+\mathrm{Mg})$ and narrowing of $\mathrm{Ca}: \mathrm{Mg}$ below the optimum value in rape seeds.

5. The value of $\mathrm{Ca}: \mathrm{Mg}$ ionic relation as well as $\mathrm{Ca}: \mathrm{P}$ and $\mathrm{N}: \mathrm{S}$ weight proportions in rape seeds under the influence of granulates A, B, C and D significantly differed from the optimal values for plants.

\section{Acknowledgements}

The study was carried out as part of the research project N 305358739 financed by the Ministry of Science and Higher Education.

\section{REFERENCES}

1. Antonkiewicz J. 2010. Effect of sewage sludge and furnace waste on the content of selected elements in the sward of legume-grass mixture. Journal of Elementology, 15(3), 435-443. DOI:105601/ jelem.2010.15.3.435-443.

2. Antonkiewicz J., Kołodziej B., Bielińska E., Gleń-Karolczyk K. 2018. The use of makroelements from municipal sewage sludge by the multiflora rose and the Virginia fanpetals. Journal of Ecological Engineering 19(6), 1-13. DOI:1012911/22998993/92889

3. Barczak B., Skinder Z., Piotrowski R. 2016. Sulphur as a factor that affects nitrogen effectiveness in spring rapeseed agrotechnics. Part II. Yield of seeds and protein. Acta Sci. Pol., Agricultura 15(4), 3-14. ISSN 2300-8504 (online)

4. Barczak B., Nowak K., Moskal M. 2017. Assessment of the nutritional status of narrow-leaf lupin of sulphur in full maturity under conditions of fertilization with this nutrient. Fragm. Agron. 34(3), 25-32.

5. Gaj R. 2010.Effect of different level of potassium fertilization on Winter oilseed rape nutritional status at the initation of the main stem growth and on the field. Oilseed Crops XXXI:115-124

6. Grygierzec B., Luty L., Musiał K. 2015. The efeciency of nitrogen and sulphur fertilization on Fields and value of N:S ratio for LoliumxBoucheanum. Plant Soil Environ. 61(3), 137-143. DOI:. org/10.17221/1005/2014-PSE

7. Grzebisz W., Przygocka-Cyna K. 2007. Springmalt barley response to element al sulphure - the prognosticvaluse of $\mathrm{N}$ and $\mathrm{S}$ concentrations in Malt barley leaves. Plant Soil Environ. 53(9), 388-394.

8. Hargreaves J.C., Adl M.S. \& Warman P.R. (2008). A review of the use of composted municipal solid waste in agriculture. Agric. Ecosys. Environ., 123:1-14. DOI. 10.1016/j.agee.2007.07.004

9. He M., Tian G., \& Liang X. (2009). Phytotoxicity and speciation of copper, zinc and lead during the aerobics composting of savage sludge. Journal Hazard. Mater., 163:671-677. DOI.10.1016./j. hazmat.2008.07.01.

10. Jarnuszewski G., Meller E. 2013. Mineral element ratios in plants grown on post-bog soils fertilised with zinc and copper. Folia Pomer. Univ. Technol. Stetin., Agric., Aliment., Pisc., Zootech. 304 (26), 25-32. (in Polish) 
11. Jamal A., Moon Y., Abdin M. 2010. Sulphur - a general overview and interaction with nitrogen. Austr. J.Crop Sci. 4:523-529.

12. Kovàćik P., Macàk M., Ducsay L., Halcćinovà M., Janćich M. 2011. Effect of ash-fly ash mixture application on soil fertility. J. Elem. 16(2), 215-225. DOI: 10.5601/jelem.2011.16.2.05.

13. Krzywy J., Krzywy E. 2001. The effect of multicomponent fertilizers on the formation of ionic ratios $\mathrm{K}: \mathrm{Mg}, \mathrm{K}: \mathrm{Ca}, \mathrm{K}:(\mathrm{Ca}+\mathrm{Mg})$ and $\mathrm{Ca}: \mathrm{P}$ in a grass mixture. Zesz. Prob. Post. Nauk Rol. 480: 253-258.

14. Krzywy J., Baran S., Krzywy E. 2002. The influence of one-and multicomponent fertilizers oh the $\mathrm{K}: \mathrm{Mg}$, $\mathrm{K}:(\mathrm{Ca}+\mathrm{Mg}), \mathrm{Ca}: \mathrm{P}$ and $\mathrm{N}: \mathrm{S}$ ionic ratios in cultivated plants. Zesz. Prob. Post. Nauk Rol. 484: 317 - 323.

15. Krzywy E., Możdżer E., Wołoszyk C. 2013. Research on the use of sewage sludge from plants producing multicomponent mineral fertilizers or deacidification of soils and improvement of environmental conditions for plant development (NE Poland). Sprawozdanie końcowe projektu badawczego NN 305358 739, 15-22.)

16. Majcherczak E , Kozera W. , Nowak K. Barczak B. 2006. Contents of macronutrients and ionic ratios in spring barley grain in the conditions of foliar fertilization with micronutrients . J. Elem. 11(1), 43-48.

17. Łabuda S., Filipek T., Dechnik I. 1992. The relation of oats to the differentiation of calcium and magnesium in a model experiment. Rocz. Gleb. 43:29-35.

18. Podleśna A., Kocoń A. 2009. The effects of sulfur and nitro gen on field and quality of Winter oilseed rape. Sulfur metabolism in higher plants. Margraf Publishers, Germany, pp. 123-127.

19. Regulation of the Minister of Natural Environment on how to conduct land surface pollution assessment dated 1 September 2016 (in Poland). Official Journal of low item. 1395 of 2016. (in Polish)

20. Schung E., Haneklaus S. 2000. Significance of interactions between sulphur and nitrogen supply for growth and quality of crop plants. In: Sulfur Nutrition and Sulfur Assimilation in Higher Plants. Eds. Brunold et al., Paul Haupt, Bern, Switzerland: 345-347.

21. Šiaudnis G. 2010. The effects of nitro gen and sulphur fertilisation on the elemenetal composition and seed quality of spring oilseed rape. Zemdirbyste-Agriculture 97(4), 47-56.

22. Stankowski S., Wołoszyk C. 2008. The consequent impact of organic fertilizers and nitrogen doses on yield and grain quality of winter triticale. Zesz. Prob. Post. Nauk Rol., 484: 623 - 628.

23. Torri S., Zubillaga, M., Cusato M. 2009. Potential of discaria americana for metal stabilization on soils amended with biosolids and ash-spiked biosolids. Int. J. Phytoremediation, 11(2), 187-199. DOI: $10.1080 / 15226510802378475$.

24. Wyszkowski M., Ciećko Z. 2002. Effect of fertilization on relations between ions in plants. Wyd., Wieś Jutra 11:7-8.

25. Wyszkowski M. 2001. The influence of magnesium on the formation of yields and mutual relations between some ions in plants. Rozprawy i Monografie, Uniwersytet Warmińsko-Mazurski, Olsztyn 52:90-95. 